\title{
MICROEARTHQUAKES IN KANSAS AND NEBRASKA 1977-87
}

\author{
Greg M. Hildebrand, Don W. Steeples, Ralph W. Knapp, \\ Richard D. Miller, and Brett C. Bennett \\ Kansas Geological Survey \\ The University of Kansas \\ Lawrence, KS 66046
}

\begin{abstract}
The Kansas Geological Survey has operated a microearthquake seismograph network since mid-1977. The network now consists of fifteen stations located in the eastern half of Kansas and Nebraska. Locatable microearthquakes with duration magnitudes less than 3.2 occur at the rate of roughly 20 per year in the two-state area, with most of the events ranging from 1.4 to 2.5 in local magnitude. The microearthquake pattern observed over the past ten years is consistent with the pattern of historical earthquakes reported since 1867. Much of the activity occurs along the Nemaha Ridge, a buried Precambrian uplift that runs from roughly Omaha, Nebraska, southward across Kansas to near Oklahoma City. This geological structure has been the site of several earthquakes of MM Intensity VII over the past 125 years. Some seismicity is observed along the northwest flank of the Midcontinent Geophysical Anomaly in Kansas, but little is observed in the Nebraska or Iowa portions of this Precambrian feature. The Central Kansas Uplift, which is a buried anticline similar in age to the Nemaha Ridge, has been the site of several felt earthquakes since 1982. A trend of earthquakes extending northeastward across central Nebraska is not associated with any prominent known geologic structure. All the seismicity in central and eastern Kansas can be roughly correlated to known geologic structures.
\end{abstract}

\section{INTRODUCTION}

At least 30 felt earthquakes with epicenters in Kansas have been documented since 1867 (DuBois and Wilson, 1978). For comparison, historical earthquakes are shown in Figure 1 and microearthquakes from 10 years' recording are shown in Figure 2. The largest of the historical earthquakes in Kansas were Modified Mercalli Intensity VII events that occurred in 1867 and 1906 in the vicinity of Manhattan. Although the geologic structure or structures responsible for these two earthquakes have not been positively identified, the following paragraphs outline the tectonic setting and provide some insight into the probable geologic structure or structures involved.

The proximity of several MM Intensity VII/VIII earthquake epicenters in Kansas, Nebraska, and Oklahoma to the Nemaha Ridge (a buried Precambrian granitic uplift) or the Humboldt Fault (the eastern boundary of the Nemaha Ridge, Figure 3) led early investigators (Lugn, 1935; Lee, 1954) to ascribe the source of seismic activity to movement on these structures. This view is also reflected in the Seismic Risk Map of the United States (Algermissen, 1969) which shows a zone two (moderate damage expected) designation in the vicinity of the Nemaha Ridge.

\section{REGIONAL SEISMOTECTONIC SETTING}

Docekal (1970) analyzed the isoseismal patterns of Intensity VII/VIII historical earthquakes in the Midcontinent and related them to basement configuration, structure, and lithology. From this he delineated the Midcontinent Seismic Trend with earthquake occurrence in central Texas, central Oklahoma, northeast Kansas, southeast Nebraska, southeast Min- nesota, and the Keweenaw Peninsula, Michigan. He concluded that the stronger earthquakes of the region were genetically related to the Arbuckle, Nemaha/Humboldt, and Midcontinent Geophysical Anomaly (MGA) structures or combinations of them. However, we doubt that earthquakes in central Texas and central Oklahoma are genetically related to earthquakes in Kansas, Nebraska, and Minnesota because late Paleozoic structures in central Oklahoma (such as

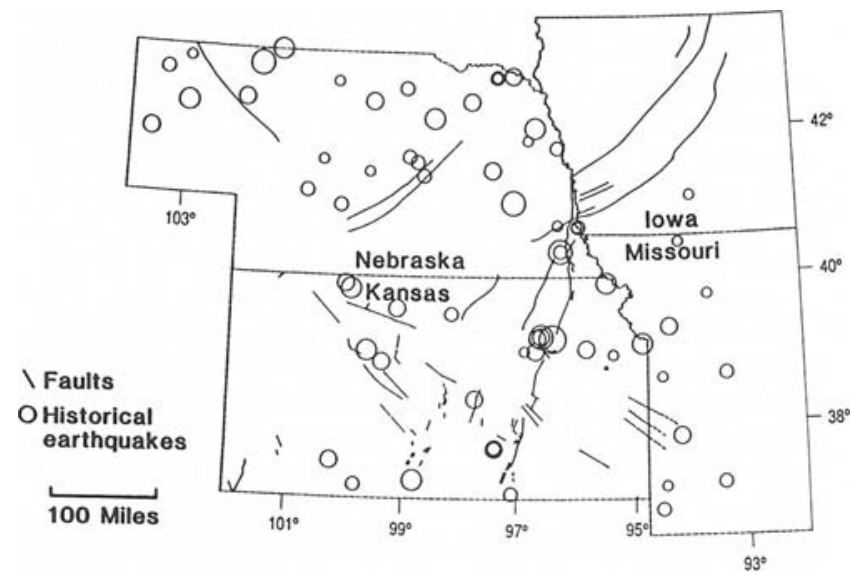

Fig. 1. Historical earthquakes are shown by sizecoded circles of Modified Mercalli Intensity. Largest events are the MM VII shown by the largest circles and the smallest events are MM III shown by the smallest circles. Faults are depicted by lines and are taken from many sources in the literature. 


\section{Hildebrand, Steeples, Knapp, Miller and Bennett}

the Arbuckle mountains) separate the Precambrian features of the north from those in the south.

The MGA has been recognized as representing an important structural feature in the Midcontinent (Ocola and Meyer, 1973). The MGA extends from the Lake Superior region southwestward at least to central Kansas and into Oklahoma (King and Zietz, 1971; Chase and Gilmer, 1973). Yarger (1981) has shown that the MGA extends southward beyond the KansasOklahoma border. Data presented by Guinness et al. (1982) suggest that the MGA extends as far south as $32.5^{\circ} \mathrm{N}, 99.6^{\circ} \mathrm{W}$ near Abilene, Texas.

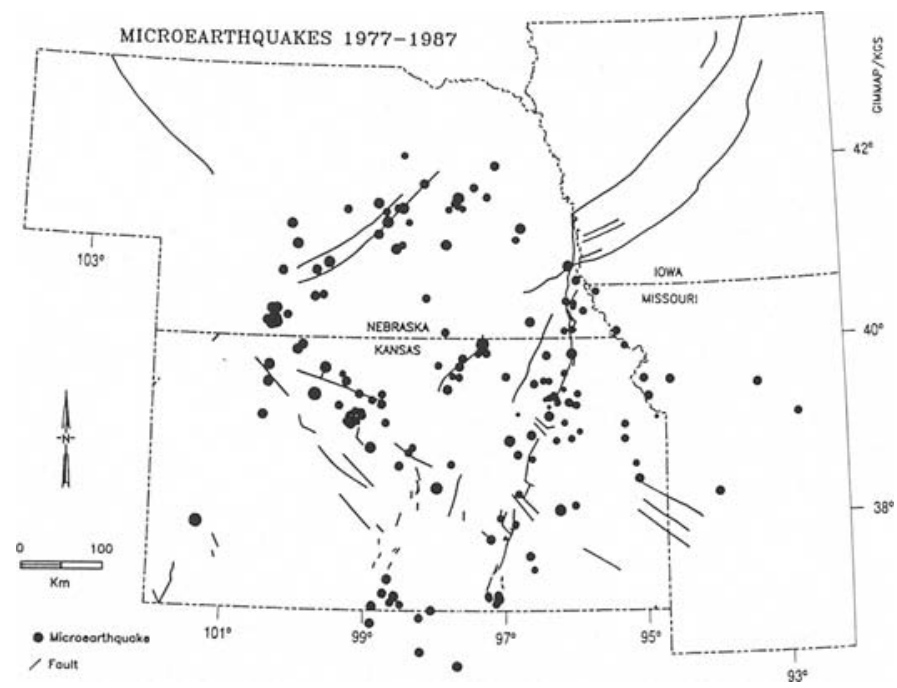

Fig. 2. Microearthquakes recorded by the Kansas Geological Survey between August 1977 and June 1987 are size-coded by local magnitude. The largest event has magnitude 3.3 and the smallest is local magnitude 0.8 . Faults plotted are identical to Figure 1.

The MGA is the largest positive gravity anomaly in North America with a length of more than $1000 \mathrm{~km}$, a width of 50 to $100 \mathrm{~km}$, and a maximum peak-to-peak amplitude of $160 \mathrm{mgal}$. It marks a thick sequence of mafic igneous rocks emplaced along a zone of major late Precambrian rifting (Ocola and Meyer, 1973). The structure is bounded by faults at the surface in the Lake Superior region, and similar bounding faults are inferred from geophysical data in the area to the south where the structure is deeply buried below younger sediments (King and Zietz, 1971). An offset of 50 to 60 $\mathrm{km}$ to the northwest in the Nebraska section of the MGA (near the Kansas-Nebraska border) is interpreted by Chase and Gilmer (1973) as a transform fault associated with the Precambrian rifting (Figure 3).

There are surface structures associated with the MGA in the Manhattan, Kansas, area. The Abilene anticline (Jewett, 1941) parallels its southeast flank and the Riley County kimberlite intrusives (Brookins, 1970) lie along the same structural trend. Emplacement of the kimberlites has been associated with right lateral strike-slip movement on a buried fault at the east flank of the Abilene anticline (Chelikowsky, 1972). The direction of movement is inferred from rotation of rock joints in the area of the possible fault. The relation of the kimberlites to this strike slip fault hypothesis is in doubt because the long axes of the intrusions are oriented northwest-southeast, perpendicular to the Abilene anticline (Cook, 1955). This indicates that the direction of least horizontal compressive stress was perpendicular to the Abilene anticline at the time the kimberlites were emplaced, a condition incompatible with strike slip parallel to the Abilene anticline. The Elk Creek, Nebraska, carbonatite (Brookins et al., 1975) also lies along the southeast flank of the MGA not far from the Kansas-Nebraska border. It appears from aeromagnetic evidence (Yarger, 1981) that all of these ultramafic intrusions are controlled or at least influenced by the faults bounding the MGA.

Recently, deep seismic reflection data have been gathered by the Consortium for Continental Reflection Profiling (COCORP) across the MGA in Kansas. These data ultimately will go far in assisting in regional interpretation of the relationship of the MGA to the Nemaha Ridge (Serpa et al., 1984) and in constructing a geologic cross-section of the MGA itself. Data from the eastern section of the COCORP line show the relatively flat-lying sediments in the Forest City basin and complex structures within the Precambrian basement at depths of 10 to $20 \mathrm{~km}$ (Brown et al., 1983). The deep Precambrian reflections become more shallow in the vicinity of the MGA and the Nemaha Ridge, suggesting 2 to $3 \mathrm{~km}$ of uplift since $1.65 \mathrm{By}$ ago which is the

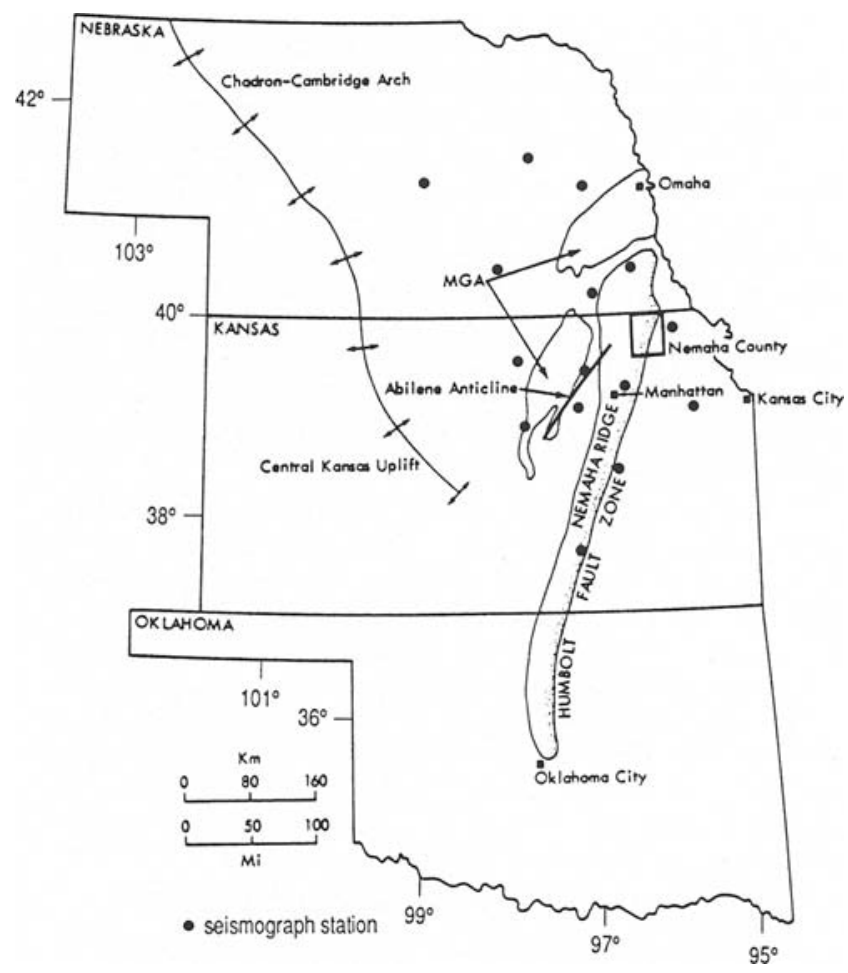

Fig. 3. Major regional tectonic features that are apparently related to earthquake activity. Nemaha County is the locality where the Nemaha Ridge was discovered by drilling in the early 1900's. 
$\mathrm{U} / \mathrm{Pb}$ Zircon-age of basement granites in the area (Bickford et al., 1979). The age of the uplift may well be Keweenawan (1.1 By ago), associated with the rifting.

The COCORP data from the MGA vicinity (Serpa et al., 1984) indicate that the Rice Formation (Precambrian sedimentary rocks that appear to be genetically related to the rift) reaches a thickness of as much as 3 to $4 \mathrm{~km}$ along the flanks of the MGA. The basalt flows within the MGA itself reach a thickness of about $8 \mathrm{~km}$. The Serpa et al. (1984) interpretation of COCORP data suggest that the Humboldt fault zone dips about $20^{\circ}$ $30^{\circ}$ to the east and that the Humboldt may be a Pennsylvanian-Permian-aged reactivation of late Precambrian faults associated with the formation of the MGA. Faults with similar dips are present on both sides of the central portion of the MGA.

\section{RESULTS FROM TEN-YEARS RECORDING}

Historical earthquakes can often be linked to specific geologic features by inference from the recording of present-day microearthquakes. The microearthquake pattern shown in Figure 2 bears a good resemblance to that shown by historical earthquakes in Figure 1 with the exception of northwestern Nebraska where there are no seismograph stations (see station map in Figure 3). This result in conjunction with other geological and geophysical studies of the past few years allows us to make useful observations about earthquake activity in Kansas. While Cole (1976) showed a single long Humboldt Fault in the basement, more recent geophysical evidence (Steeples, 1982) indicates that a zone of faulting perhaps tens of kilometers wide exists along both sides of the Nemaha Ridge. This conclusion is drawn in part from the scatter in both the historical and microearthquake seismicity and in part from other geological and geophysical evidence. Seismic-reflection surveys, including unpublished proprietary data, indicate a myriad of faulting along both sides of the Nemaha Ridge. Gravity and aeromagnetic data are consistent with a multitude of unmapped subsurface faults. Drawing on these data and LANDSAT lineaments, Berendsen and Blair (1986) have examined cuttings from hundreds of wells on both sides of the Nemaha and has hypothesized faulting between basement crustal blocks.

The earthquakes located using the KansasNebraska network can be grouped into four distinct seismic trends. A large portion of the events lie astride the Nemaha Ridge and indicate low levels of seismicity on faults associated with or bounding the ridge. A trend of events roughly parallel to the ridge, but about $100 \mathrm{~km}$ to the west of it is associated with the MGA. Intersecting these trends from the northwest is a belt of earthquake activity that during the first five-to-six years of network operation had only sparse activity; however, recently a marked increase in earthquake activity has been observed. This northwest-southeast trend is related to the faults flanking the Central Kansas Uplift. Lastly, and least understood geologically, is a band of earthquakes that is oriented northeastsouthwest across central Nebraska. This trend of earthquakes has no named geologic structure associated with it, but there are a pair of normal faults shown on the USGS/AAPG tectonic map that are coin- cident with the trend. The central Nebraska trend intersects the Central Kansas Uplift at nearly a right angle. There is a strong concentration of seismicity at that intersection (Evans and Steeples, 1987).

The occurrence of microearthquakes along the approximate trace of the Humboldt Fault zone implies the possible occurrence in the past and in the future of earthquakes with body-wave magnitudes up to $51 / 2$ which was the probable approximate magnitude of the 1867 "Manhattan" earthquake. Fault segments in the basement are easily long enough to accommodate infrequent earthquakes up to at least magnitude 6 . Previously unknown felt reports from the 1867 earthquake (Modified Mercalli Intensity VII) suggest that the epicenter may have been east of Manhattan near the known Humboldt Fault trace (DuBois and Wilson, 1978) rather than "22 miles northwest of Manhattan" (Merriam, 1956).

The series of felt earthquakes in the Manhattan vicinity in 1929 are no longer enigmatic in regard to their structural source. Isoseismal patterns clearly indicate that the epicenters were 20 to $40 \mathrm{~km}$ west of the main trace of the Humboldt Fault. As detailed earlier, however, there are other structures in the Manhattan area that may be responsible for some of the historical earthquakes. The pattern of microearthquakes along the Nemaha Ridge is diverse, suggesting that several faults are capable of producing small-to-moderate earthquakes. At least one microearthquake has occurred in the area south of Junction City, $20 \mathrm{~km}$ west of the Humboldt Fault.

The recent increase in earthquake activity along the Central Kansas Uplift has been documented on earthquake seismograms and by earthquake-felt reports. The majority of the felt reports were from 8 events located in Rooks, Graham, and Ellis counties. This group of events can be clearly identified on the microearthquake epicenter map (Figure 2). A large majority of the felt reports were from people whose homes are built on alluvial deposits along the Saline River.

One of the most important seismic observations in western Kansas and central Nebraska is the relatively high level of seismicity at the intersection of the northwest/southeast trend through central Kansas and the northeast/southwest trend through central Nebraska. Although this intersection is coincident with the Sleepy Hollow oil field, we believe that a series of microearthquakes in this region (at least some of them) are tectonic in nature rather than induced by water-flood operations in the oil field. Pleistocene and/or recent tectonic upwarping centered along the Chadron-Cambridge arch (Figure 3) is suggested by anomalous stream gradients and knick-points where rivers cross the arch in south-central Nebraska (Stanley and Wayne, 1972), indicating tectonic activity was present before oil production began. Woollard (1958) also suggested on the basis of the historical seismicity record that the Central Kansas Uplift-ChadronCambridge arch system, was tectonically active (Figure 1.) It is worth noting that other water-flood operations within oil fields along the Central Kansas Uplift do not 


\section{Hildebrand, Steeples, Knapp, Miller and Bennett}

cause earthquake activity.

A single event recorded with an epicenter near Lakin, Kansas, was of sufficient size (MDUR=3.0) to be felt by people over a relatively small area. The lack of any located epicenters below MDUR $=3.0$ in the area is not surprising considering the lack of sensitivity of the network that far from the primary monitoring area.

Recent earthquake analysis has involved both digital data and standard drum-recorded analog data. Refraction-type crust/mantle studies (Miller, 1983; Steeples and Miller, 1989) have included both earthquake data from the Kansas-Nebraska network and explosion refraction data. The general seismicity (Evans and Steeples, 1987) and an estimation of the source parameters of earthquakes in the Sleepy Hollow oil field in Red Willow County, Nebraska (Wallace, 1986), have been derived from analysis of microearthquake data. The earthquake data sets are continuously updated in order to determine more representative composite interpretations of crust/mantle structures and properties.

The regional network in eastern Kansas and eastern Nebraska has a typical station spacing of about $200 \mathrm{~km}$. It has not been possible to develop focal mechanisms for microearthquakes because almost all readings are made near the edges of the focal sphere.

Location parameters and arrival times for all Kansas and Nebraska microearthquakes from 1977 through 1984 are given in Steeples et al., 1988.

\section{CONCLUSIONS}

1. The microearthquake pattern established over a ten-year period in the Kansas vicinity bears good resemblance to the historical pattern established over the past 125 years of recorded history.

2. The vast majority of the microearthquakes in Kansas can be related directly to the Nemaha Ridge/Humboldt Fault zone, the Midcontinent Geophysical Anomaly and its southward extension into Oklahoma, and the Central Kansas Uplift.

3. A large number of faults exist in the vicinity of these major structures. These faults are likely capable of generating earthquakes in the bodywave magnitude range of 5 to $51 / 2$.

4. Correlation of the Sleepy Hollow oil field with the intersection of seismic trends and geomorphic evidence of tectonic uplift in Pleistocene and/or recent time suggests that at least some of the earthquakes in the oil field are tectonic in nature.

\section{ACKNOWLEDGEMENTS}

Financial support was provided in part by the $\mathrm{U}$. S. Nuclear Regualtory Commission under Contracts NRC-04-82-006-02, and NRC-04-87-084, by the Nation Science Foundation under Grant EAR-82-19-076, and by the U. S. Geological Survey under Contract No. 1408-0001-21880.

\section{REFERENCES}

Algermissen, S. T. (1969). Seismic risk studies in the United States; in Proc. of Fourth World Conf. on
Earthquake Engr., Santiago, Chile, 1, 14-27.

Berendsen, P. and K. Blair (1986). Subsurface structural maps over the CNARS with discussion, Kansas Geological Survey, over-size maps, scale 1:250,000, $20 \mathrm{pp}$.

Bickford, M. E. , K. L. Harrower, R. L. Nusbaum, J. J. Thomas, and R. E. Nelson (1979). Preliminary geologic map of the Precambrian basement rocks of Kansas, Kansas Geological Survey Map M-9, Scale 1:500,000.

Brookins, D. G., S. B. Treves, and S. L. Bolivar (1975). Elk Creek, Nebraska, carbonatite: Strontium Geochemistry, Earth and Planetary Science Letters 28, 79-82.

Chase, C. G. and T. H. Gilmer (1973). Precambrian plate tectonics: The Midcontinent gravity high, Earth and Planetary Science Letters 21, 70-78.

Chelikowsky, J. R. (1972). Structural geology of the Manhattan, Kansas, area, Kansas Geological Survey Bull. 204, pt. 4.

Cole, V. B. (1976). Configuration of the top of the Precambrian rocks in Kansas, Kansas Geological Survey Map M-7, scale 1:5000,000, 1 sheet.

Cook, K. L. (1955). Magnetic surveys over serpentine masses, Riley County, Kansas, Mining Engineering 7, 481-488.

Docekal, J. (1970). Earthquakes of the Stable Interior with emphasis on the Midcontinent, Ph. D. thesis, University of Nebraska.

DuBois, S. M. and F. W. Wilson (1978). List of earthquake intensities for Kansas, 1867-1977, Kansas Geological Survey, Environmental Geology Series 2.

Evans, D. G. and D. W. Steeples (1987). Microearthquakes near the Sleepy Hollow oil field, southwestern Nebraska, Bull. Seism. Soc. Am. 77, $132-140$.

Guinness, E. A., R. E. Arvidson, J. W. Strebeck, K. Schultz, G. F. Davies, and C. E. Leff (1982). Identification of a Precambrian rift through Missouri by digital image processing of geophysical and geologic data, J. Geophys. Res. 87, 85298545 .

Jewett, J. M. (1941). The geology of Riley and Geary counties, Kansas, Kansas Geological Survey Bull. 39.

King, E. R. and I. Zietz (1971). Aeromagnetic study of the Midcontinent gravity high of central United States, Geol. Soc. Am. Bull. 82, 21872208.

Lee, W. H. K. (1954). Earthquakes and Nemaha anti- 


\section{Microearthquakes in Kansas and Nebraska 1977-1987}

cline, Am. Assoc. Petr. Geol. Bull. 38, 338-340.

Lugn, A. L. (1935). The Nebraska earthquake of March 1, 1935, Science 81, 338-339.

Merriam, D. F. (1956). History of earthquakes in Kansas, Bull. Seism. Soc. Am. 46, 87-96.

Miller, R. D. (1983). Crustal structure in Kansas from regional earthquake seismograms, M. S. thesis, Dept. of Physics, University of Kansas, Lawrence, Kansas Geological Survey Open-file Report 83-21.

Ocola, L. C. and R. P. Meyer (1973). Central North American Rift System 1: Structure of the axial zone from seismic and gravimetric data, J. Geophys. Res. 78, 5173-5194.

Serpa, L., T. Setzer, H. Farmer, L. Brown, J. Oliver, S. Kaufman, J. Sharp and D. W. Steeples (1984). Structure of the southern Keweenawan rift from COCORP surveys across the Midcontinent Geophysical Anomaly in northeastern Kansas, Tectonics 3, 367-384.

Stanley, K. O. and W. J. Wayne (1972). Epeirogenic and climatic controls of early Pleistocene fluvial sediment dispersal in Nebraska, Geol. Soc. Am. Bull. 83, 3675-3690.
Steeples, D. W. (1982). Structure of the Salina-Forest City interbasin boundary from seismic studies, University of Missouri-Rolla, Journal 3, 55-81.

Steeples, D. W., G. M. Hildebrand, B. C. Bennett, R. D. Miller, Y. Chung, and R. W. Knapp (1988). Kansas-Nebraska seismicity studies using the Kansas-Nebraska microearthquake network, $U$. S. Nuclear Regulatory Commission, Washington, $D$. C. , Final Report NUREG/CR-5045-RA, NRC FIN B8272, Contract no. NRC-04-82-006-02.

Steeples, D. W. and R. D. Miller (1989). Kansas refraction profiles; in Proc. of Symposium on Geophysics in Kansas, D. W. Steeples, compiler, Kansas Geological Survey Bull. 226, 133-168.

Wallace, K. D. (1986). Estimation of source parameters for microearthquakes near the Sleepy Hollow oil field, Red Willow County, Nebraska, University of Kansas Masters Thesis, 96 p.

Yarger, H. L. (1981). Aeromagnetic survey of Kansas, EOS Am. Geophys. Union Trans. 62, 173-178.

Received May 31, 1988

Revised December 5, 1988

Accepted December 8, 1988 